\title{
6 \\ Civil Society and the Political Legitimacy of Regional Institutions: An NGO perspective
}

\section{Maureen Penjueli}

'Citizens' voices about the kind of Pacific that is emerging are not being heard in the absence of coherent, effective regional governance - Sir Mekere Morauta (Pacific Plan Review 2013).

Across the Pacific, the regional network of intergovernmental agencies is matched by networks of church, non-government and community organisations. The Malua Conference of Churches and Missions, held in Samoa in 1961, led to the founding of the region's largest ecumenical body, the Pacific Conference of Churches (PCC), in 1966. For 25 years, the Pacific Concerns Resource Centre (PCRC) served as a regional hub for the Nuclear Free and Independent Pacific (NFIP) movement. Today, networks such as the Pacific Islands Association of Non-Government Organisations (PIANGO), the Pacific Network on Globalisation (PANG), and the Pacific Islands Climate Action Network (PICAN) campaign on development, trade, oceans and climate change.

In many cases, civil society organisations (CSOs) have initiated or led regional debates on key concerns. The NFIP movement campaigned for a nuclear-free zone for years before governments adopted the Rarotonga Treaty, establishing the South Pacific Nuclear Weapon Free Zone (SPNWZ). Women's organisations have led the regional debate on gender-based violence in the home, workplace and 
community. Churches and women's groups played crucial roles in peacebuilding during conflicts in New Caledonia, Bougainville, and Solomon Islands, well before regional peacekeeping interventions arrived.

For many years, governments and donors have announced that they value the role of CSOs in regional initiatives. But this commitment is not matched by concrete, ongoing and cost-effective mechanisms for engagement with the diverse range of organisations that are branded as 'civil society' or 'non-state actors'. This chapter is based on the actual experiences of CSOs in their efforts to engage and participate in regional institutions - particularly the Pacific Islands Forum (PIF) and Melanesian Spearhead Group (MSG) — for almost two decades. It highlights what lessons can be offered to the newest regional structure, the Pacific Islands Development Forum (PIDF), in terms of CSO inclusion. The paper uses real examples to show how the politics that keep CSOs out of regional institutions and constrain the openness of debates on key issues have been to the detriment of Pacific societies. It also highlights what CSO organisations offer Pacific regionalism.

\section{The Significant Role of CSOs in Regionalism}

It is continually stated (South Pacific Forum Secretariat 2000) that the island economies of the Pacific, because of their size and geographical position, have limited access to the skills, information and finance needed for successful global integration and economic growth. It is commonly argued that regional institutions and organisations are able to overcome such shortcomings by pooling human resources, and attracting and retaining highly skilled personnel. By operating regionally, economies of scale allow for sharing of technology and knowledge, and provide administrative savings.

Regional cooperation can also give island countries a more persuasive voice on the world stage and help secure a more favourable external economic and political relationship, rather than be overwhelmed by large and powerful nations who can dictate the terms of such relationships.

The role and importance of CSOs and their contributions to economic, social, cultural and political development have long been recognised at the global level. The United Nations Development Program (UNDP), for example, argues that CSOs:

1. provide basic services, such as primary education, health care, clean water and sanitation, facilitate participation of communities in local planning and budgeting purposes; 
2. advocate for rights; and

3. provide special consideration for marginalised groups through the provision of counselling and support services.

Historically, in the Pacific, social movements supported by CSOs have played a key role in the struggle for the right to self-determination and the pursuit of the region's own development goals. In the Pacific regionalism of the 1970s to the 1990s, there was often political solidarity between Pacific Island governments and CSOs, where external interests were evidently detrimental to the interests of the region. The greatest successes by Pacific Island countries at the international level have been in the pursuit of 'collective diplomacy', ' where social movements and the state have worked alongside each other to hold overseas governments to account in order to achieve significant wins, such as the Law of the Sea Convention, the London Dumping Convention, and to help secure a nuclear-free Pacific and a ban on drift-net fishing.

Much of this success would not have happened had CSOs not provided support (or even led), and provided technical knowledge, outlined moral obligations, and utilised their networks, communication and advocacy skills. Perhaps most significantly, CSOs often gave regional institutions legitimacy by providing direct links to social movements and their issues of concern.

\section{Lack of Formal Recognition and Inclusive Processes}

Despite the obvious successes of collective diplomacy and the contribution of CSOs to that effort, it was not until 1995 that the PIF, the region's premier political body, officially recognised this fact. Since 1995, PIF leaders have expressed a need to engage with CSOs, to widen the field of participation in regional and international matters, beyond the members of the forum donors and development partners known as dialogue partners. Yet despite the numerous declarations by leaders and recommendations by independent reviews of the regional body recognising the importance of CSOs, no effective mechanisms for CSO engagement have been developed. ${ }^{2}$

\footnotetext{
1 In the description used by the University of the South Pacific academic Greg Fry (1994, pp. 70-71).

2 See IDEA (2014). The first substantive review of the Pacific Island Forum Secretariat in 2003 contained a landmark decision in which PIF leaders resolved to see how they could better interact with CSOs. In 2004, PIF leaders acknowledged the views of CSOs in a PIF communiqué. Leaders noted the importance of CSOs again six years later in 2009, and again in 2011 in the Waiheke Declaration.
} 
By Pacific Island Forum Secretariat's own admission (see PIFS 2012) there is no protocol for dialogue between CSOs and the regional institutions that are members of the Council of Regional Organisations in the Pacific (CROP). Although some regional institutions have higher levels of CSO engagement, PIF still lacks a formal policy for interaction and liaison with CSOs in the region. After intensive negotiations between CSOs and the PIFS, an accreditation policy was established. It is focused solely on regulating which CSOs would gain observer status at meetings hosted by the PIFS. In other words, it has focused on who can watch, not on who can participate.

While CSOs face significant hurdles in obtaining the recognition needed to get a foot in the door - let alone a seat at the table - there has been an exponential increase in the number of new associate members, observers, and dialogue partners of the Pacific's political club. This is a growing reflection of the changing geopolitical landscape of the region; powerful forces are at work in the Pacific, which is making the regional institutional political space highly contested.

Today, PIF meetings are open to many observers, including foreign governments as far away as Cuba and Israel, multilateral institutions such as the World Bank, the Asian Development Bank, the Commonwealth Secretariat, and UN agencies, as well as private sector organisations. Private sector organisations, including commercial banks, are enjoying access to forum leaders and in recent years have started to sponsor events at the leaders meetings. Development partners and observers now outnumber Pacific Island governments.

\section{Alarm Bells about Legitimacy of Regional Architecture}

Our regional institutions exhibit a clear democratic deficit. Each year the list of observers grows, giving the PIF a sense of global legitimacy while failing to regain legitimacy in the eyes of the peoples of Oceania. A recent review of the PIFS found that even island governments generally feel alienated from the organisation and that there needs to be greater participation and ownership by members (PACNEWS 2015).

Over the last decade, alarm bells have been repeatedly rung by CSOs and many regional observers about regionalism, in particular the legitimacy of regional systems (both technical and political) and whether these spaces are democratic spaces. The 2013 review of the Pacific Plan for Strengthening Regional Cooperation and Integration, led by former Papua New Guinea Prime Minister 
Sir Mekere Morauta, noted: 'Citizens feel that the right conversations are not being had about the region's new vulnerabilities - social, economic, political and environmental' (Pacific Plan Review 2013).

Key questions posed by many experts are:

1. Who is Oceania for?

2. What does the community stand for; what are its values, practices and ideas?

3. Who should be regarded as belonging to the community, on what basis?

4. Who should speak for it and determine its practice?

National parliaments appear to have lost part of their power to scrutinise the positions taken by their ministers at the regional level, and there are no functional formal mechanisms to link the views of the people on political matters to the agenda of regional institutions such as the PIF. For too long, the public attitude has been one of 'permissive consensus', meaning that regional policies were taken for granted by the Pacific people as an accepted part of the political landscape.

CSOs, as the alternative voice and the bridge between the broader public view, and regional institutions have for a long time been deliberately kept out by the lack of a formal mechanism for engagement with PIFS.

\section{Critical Moments in Regional Architecture and Diplomacy}

The suspension of Fiji from the PIF after its fourth coup set in motion a series of events that challenged existing regional structures. The Fiji government, seizing the moment and the opportunity presented by a perception of an Australiacentric PIFS, deliberately pursued an agenda of regional self-determination and set about reshaping regional diplomacy and architecture based on this principle. In doing so, CSOs were offered a platform on which they could revisit the question of the legitimacy of the regional architecture. At the sub-regional level, Fiji's suspension from the various regional and international clubs only served to strengthen its resolve to work with Melanesian leaders in a 'Pacific way', without the participation of New Zealand and Australia. Fiji's chairmanship of the MSG in 2011 was a turning point for Fiji and the MSG: it signalled that a determined MSG wanted to play a major role in setting the region's development agenda without the formal involvement of their big brothers, Australia and New Zealand. 
Australia and New Zealand are full members of the forum and are also the region's major donors. The Fiji government's intervention in regional debates has become a lightning rod for criticism from some regional leaders. But Fiji's suspension from forum activities has allowed it to advance opinions that go outside the forum consensus. Fiji has persuasively argued that Australian and New Zealand foreign policy interests have dominated, at times contrary to the interest of Pacific Island countries, a sentiment that resonates with many Pacific Island governments.

Indeed, we have seen an era of increased pressure from traditional allies, particularly Australia, to undertake extensive market driven economic and political initiatives in regional spaces that Pacific Island leaders have sometimes regarded as intrusive, disruptive, and even hostile (Wesley-Smith 2007).

As a direct response, the Fiji government has participated in other international networks, such as the Non-Aligned Movement (NAM) and the G77 plus China grouping, using these platforms to debate south-south cooperation. Fiji also set up the PIDF, a move widely regarded as setting up a direct rival to the PIFS, premised on the argument that the Pacific needed a space in which Pacific Islands governments could meet to discuss issues of importance to Pacific Islanders without Australia and New Zealand.

After a successful return to democracy with the September 2014 elections, Prime Minister Bainimarama argued that Australia and New Zealand should move from full members to dialogue partners of the PIF, presenting this as a condition to Fiji's re-entry into the forum. While this debate has also opened up a much needed space to debate how to effectively include CSOs in regional institutions and place peoples' issues at the centre of policy-making, it also opens up many dilemmas for CSO participation.

\section{CSOs and the Pacific Islands Development Forum}

The PIDF claims it will be an inclusive institution, particularly of CSOs. PIDF's inclusion of CSOs is relatively new and the jury is still out; it remains to be seen whether this is merely lip service. CSOs are not just focused on the domination of Australia and New Zealand, but also on the collusion of powerful interests, including multilateral financial institutions such as the Asian Development Bank (ADB) and World Bank. The ADB and World Bank - as well as many other donors — have been pursuing a very specific neoliberal governance and 
economic integration agenda in the region that in many ways is unchallenged, and yet is in direct conflict with the interests of Pacific peoples. CSOs seek to act as a counter-influence and alternative voice to these powerful interests.

The litmus test for PIDF is whether it can counter the influence of external non-regional members, particularly China and Indonesia, who will also seek to influence the PIDF in ways that undermine a self-determination agenda for the Pacific. The involvement of Indonesia in Pacific regionalism demonstrates the complexities that can quickly come into play. Indonesia has grasped the significance of being intimately involved in regional power plays, whether through MSG, PIF, or PIDF. The growing public support in the Pacific for the West Papuan freedom movement has, no doubt, played a significant role in Indonesia's foreign policy strategy.

Given the ecumenical movement's long-standing support for churches in West Papua, the PCC's Secretary General has asked: 'What agenda do Indonesia and other development partners bring to the PIDF; are they to replace the dominance that Australia and New Zealand have been accused of within the regional architecture centred in the Pacific Islands Forum?'3

Indonesia's intentions were exposed on 13 March 2015, when PNG Loop detailed Indonesia's proposal for the five Melanesian provinces of Indonesia to become a full member of the MSG. This can only be regarded as a direct attempt to block the application for MSG membership by the United Liberation Movement for West Papua, supported by Vanuatu and New Caledonia's Kanak and Socialist National Liberation Front (Front de Libération Nationale Kanak et Socialiste (FLNKS)) independence movement.

We can only assume that Indonesia will not stop at the MSG; once it gains membership it would then apply, at the invitation of the Papua New Guinea government, for full membership to PIF and possibly PIDF. Politics makes for strange bed fellows, but the long-term implications of Indonesia being a full member of MSG, PIF, and PIDF need to be seriously considered against a right to self-determination push by Fiji and other Pacific Island nations.

\section{No People's Voice in Regional Institutions}

In political science, legitimacy is usually understood as the public's popular acceptance and recognition of the authority of a governing regime (in this case regional institutions), where the authority exercises political power through

3 As questioned by the Pacific Conference of Churches General Secretary Francois Pihaatae during the welcoming of the President of Indonesia to open the PIDF meeting in 2014. 
consent and mutual understanding, not coercion. Legitimacy assumes popular consent; but who gives consent and on behalf of whom is the consent given in these regional political spaces?

Regional meetings, particularly those hosted by PIFS, are conducted behind closed doors and are increasingly subject to secret diplomacy, without a chance for the people whose lives will be deeply affected to have a direct say. This is particularly worrying when we consider that PIF covers matters that affect the ordinary person on the street. Australian and New Zealand interests are decidedly different from and, in some cases, contrary and even hostile to those of Pacific Island countries, regarding such issues as security, economics and trade, climate change, and decolonisation. Yet, increasingly, at the international level - particularly at the United Nations, the G20, and the World Trade Organization - Australia and New Zealand claim to 'represent' Pacific Island nation views by virtue of their membership in PIF.

Given the growing tensions between members over the PIF's 'consensus' policies on climate, trade and decolonisation, there is growing criticism over the lack of ownership of the forum, not just by countries but also by CSOs. In response to this challenge, PIFS initiated yet another program aiming to promote good governance in the Pacific by strengthening dialogue and engagement on policy development and implementation between the PIF and its secretariat and nonstate actors (NSAs).

According to PIFS, there is an acceptance of the criticism of a lack of 'people's voice' in regional policies: 'There is no regional government or parliament for the Pacific. As a result, if NSAs wish to contribute to regional policies, they must go through the PIFS, whose membership comprises all the national governments in the region' (see PIFS 2012). (Note the 'if' in this sentence, as though there were any doubt that CSOs wish to engage regional policy-making.)

The analysis states that member states of the PIF generally acknowledge that NSAs have strengths in:

- communicating with and engaging civil society; and

- determining public sentiment concerning the current and potential impacts of policies and ongoing or planned government interventions. Governments also recognise they may lack these capacities themselves.

However, many governments perceive NSAs as activist groups that attempt to raise and exploit public sentiment on certain development issues, in order to promote opposition to government policies and strategies. Accordingly, despite some promising shifts towards greater openness, consultations with NSAs still tend to be limited in practice. The focus on CSOs' roles in carrying government 
policies to grassroots communities dismisses the fact that CSOs have long been engaging with regional policy issues, either to highlight emerging issues of interest, which governments may not necessarily be aware of, or to bring up issues that many governments would prefer to ignore (such as decolonisation issues in West Papua, French Polynesia, New Caledonia, Guam, and Rapa Nui).

Governments too often regard CSOs as seeking to exploit public sentiments on certain development issues, which are contrary to government policies and strategies such as deep sea mining (DSM). But in the absence of a regional mechanism for accountability, it is the role of CSOs to hold governments to account.

While the PIFS would like to regard itself as the gatekeeper, controlling entry into regional policy-making, the PIFS' delay in developing a formal mechanism for CSO engagement means that many CSOs have already climbed the fence and developed other sophisticated mechanisms for engaging in regional policymaking. This includes participation in national government delegations and policy-making committees, much to the ire of some government leaders and some technocrats at the secretariat.

In many cases, specific issues are allowed to dominate PIF's policy on CSO engagement rather than letting policy dictate the terms of engagement.

There are three immediate examples where our regional institutions - PIFS in particular - are being captured by specific interest groups, whether these are foreign governments, multilateral financial institutions or other technical agencies.

\section{Seabed Mining}

In recent years, CROP agencies have been working to develop legal frameworks and policy documents to support DSM of strategic minerals in the vast exclusive economic zones of forum island countries (FICs). Through a project at the Secretariat of the Pacific Community's (SPC) geoscience division (formerly SOPAC), funded by the European Union, the mining industry is already being given 'legitimacy' by regional institutions: the CROP debate is focused on how to facilitate seabed mining rather than asking whether it should be? 
NGOs around the region argue that the EU-SPC DSM project sets out a number of dubious and unfounded assertions about seabed mining. ${ }^{4}$ Working with lawyers, scientific organisations, customary landowners, and community groups, these groups argue that the current initiative contravenes numerous international legal norms, such as the precautionary principle and the right to free and prior informed consent.

The Oceans Declaration signed by forum leaders in Palau in 2014 unfortunately supports the EU-SOPAC DSM project rationale. It has given political legitimacy to the industry to plunder the ocean floor of its wealth, by deliberately weakening any efforts to regulate an untried and untested industry. On this issue, CSOs have real grounds (scientific, economic, legal, social, cultural and moral) to challenge the policy interpretations of the PIF-mandated EU-SPC DSM project. CSOs who argue that the question of 'how' should only be discussed after the question of 'if' has first been debated are routinely excluded. Consultation is only sought on policies for seabed mining rather than questioning whether it should be allowed. The effect of this is that there has been no real debate on seabed mining, and dubious claims to legitimacy under the precautionary principle have, by and large, gone unchallenged.

\section{Regional and Economic and Trade Integration}

In 2009, the PANG released a report, titled 'Speaking Truth to Power', which documented the Australia's and New Zealand's use of power, aid, and at times coercion, to force the launch of the controversial Pacific Agreement on Closer Economic Relations (PACER) Plus negotiations. The trade talks officially commenced after the Cairns Forum meeting in 2009, even though it was abundantly clear that most Pacific Island governments were reluctant to launch negotiations. PACER Plus was launched amidst a flurry of bullying and cheque book diplomacy. Australia and New Zealand are amongst the biggest aid donors to the region, and FICs are dependent on access to funding, limiting their ability to argue against an agreement that is in Australia's and New Zealand's interests.

As negotiations gather steam for completion by December 2015, the implications are only just becoming clear. PACER Plus is far from being a balanced agreement. FICs are being pushed to make binding commitments, and the vast majority of concessions, in exchange for the status quo on labour mobility and possibly

\footnotetext{
4 CSOs such as Act Now! PNG, Bismarck Ramu Group, Pacific Conference of Churches, Lutheran Church of Papua New Guinea (with a membership of over one million), and Melanesian Indigenous Land Defence Alliance, as well as feminist groups, student movements, and academics have called for a ban on seabed mining in the Pacific.
} 
some extra aid money to assist with structural adjustment. The sad reality is that PACER Plus will constrain the ability of FIC governments to shape our development future.

Pacific CSOs have expressed their deepest concerns at the direction, content, pace and process for consultation of state negotiations toward the proposed regional free trade agreement. The PIFS has organised briefings for NSAs, but CSOs, social movements and community networks that are trying to shine a light on negotiations from the outside are not able to attain even observer status. CSOs have therefore called for:

- the immediate suspension of the PACER Plus negotiations until there has been informed, comprehensive dialogue with civil society to ascertain whether there is a popular mandate for such negotiations;

- the immediate release of all negotiating texts to allow full, comprehensive and informed input from civil society; and

- following the release of the texts a properly funded social, cultural, environmental and human rights impact assessment be undertaken to determine the impacts of any proposed outcome (Pacific civil society organisations 2015).

None of the above requests should cause democratic and transparent institutions any concerns; after all, the agreement is supposed to be for our benefit.

\section{Political Self-Determination}

Surprisingly, in 2015 Oceania is home to some island nations and territories whose people are still fighting for the right to self-determination, notably West Papua, Kanaky, Bougainville, Tahiti, and Hawai'i. CSOs have a long history of actively supporting and being part of right to self-determination struggles. They have been central in some cases, long after Pacific Island governments changed their policy to 'non-interference' in sovereign matters.

On the issue of West Papua and Tahiti, the Australian government has been largely mute in the face of atrocious human rights abuses, primarily because of their strong bilateral relationship with the Indonesian and French governments. Compare and contrast this stance with Australia's reaction to Fiji's last coup. As pointed out by Nic Maclellan (2002), 'decolonisation might not look like a hot-button issue but after our (Australia's) Security Council win we'll have to start taking it seriously in the Pacific'. 


\section{Politics of Inclusiveness}

In all of these cases, PIFS seeks to justify its position by reference to its mandate from its member states. At the same time, it openly acknowledges in its own policy documents that there is no peoples' voice in regional policies. CSOs such as PANG and the media have experienced first-hand the extent to which the forum secretariat will go to control access to their closed meetings. At the 2013 forum trade ministers meeting in Samoa, even the small public spaces which CSOs and the media used to access trade officials and ministers were rapidly closed down by secretariat staff (Samoa Observer 2013). That the secretariat would even attempt to close down public spaces where officials and CSOs and media could meet speaks to the gatekeeper mentality of some technocrats.

The continued exclusion of CSOs from regional engagement dismisses the technical knowledge (scientific, legal, environmental, social, and cultural), values, and extensive networks that CSOs can bring to the table. This expertise has been the basis of cooperation with governments from independence till today. The reason why it has taken PIFS this long to adequately address the issue of CSO engagement is because inclusiveness is, by its very nature, political. Governments instinctively do not want to work with what they call 'lobby and advocacy groups' that do not toe the line. The emphasis in terms of engagement has been to regulate who, how, when and where CSOs can attend regional spaces. A lack of a formal mechanism for engagement leaves the power in the hands of technocrats to arbitrarily determine who can and cannot attend. This informal mechanism leaves not just CSOs, but also the wider community, at the mercy of technocrats.

Regional institutions often seek to find one CSO network as their favoured interlocutor. This effort is self-defeating; 'civil society' across a region as vast as the Pacific is incredibly diverse, and it is difficult for one organisation to claim legitimacy. Instead, CROP agencies should recognise that the diversity of Pacific churches, NGOs and customary groups as a strength rather than a weakness. Regional institutions should provide a variety of mechanisms to engage with communities in a region noted for its geographic, cultural and political diversity.

More than this, the citizens of the Pacific want more than token, one-off consultations with their regional institutions. Surely, in the 21 st century, CROP agencies should recognise that good development practice involves ongoing, interactive and well-resourced engagement with people affected by the policies adopted by governments and donors. Existing attitudes and practices do a disservice to the Pacific and its regional institutions. PIFS in particular is increasingly viewed by many as an organisation seeking to facilitate the 
interest of those in power or those with money. CSOs argue that an organisation confident in its role and its mandate should welcome all views and seek ways to actively allow those views a space.

Regional CSOs demand a formal mechanism and an honest policy which is applied evenly and openly, regardless of the issue in question. The questions that the region faces are too important to be left in the hands of unelected technocrats, however well-intentioned they may be. PIDF has a unique opportunity to lead the way. Let us hope it has the courage and political leadership to engage all views even those that are contrary to PIDF's position.

The time has come for an honest debate; are our leaders prepared to allow it?

\section{References}

Fry, G., 1994, 'Climbing Back onto the Map?: The South Pacific Forum and the new development orthodoxy', Journal of Pacific History 29(3), pp. 64-72.

International Institute for Democracy and Electoral Assistance (IDEA), 2014, 'The Pacific Islands Forum and its Engagement with Civil Society Organizations' in R. Cordenillo and K. Gardes (eds), Inclusive Political Participation and Representation: The Role of Regional Organizations, International IDEA, Stromsburg. Available at: www.idea.int/publications/ inclusive-political-participation-and-representation/upload/InclusivePolitical-Participation-chapter2.pdf.

Maclellan, N., 2012, 'The Diplomacy of Decolonisation', New Matilda, 24 October. Available at: newmatilda.com/2012/10/24/diplomacy-decolonisation.

Pacific Island Forum Secretariat (PIFS), 2012, 'Programme for Strengthening Non-State Actor Engagement in Regional Policy Development', unpublished PIFS project document.

Pacific Plan Review, 2013, 'Report to Pacific Leaders', Pacific Islands Forum Secretariat, Suva, Fiji. Available at: www.cid.org.nz/assets/Key-issues/ Pacific-development/Pacific-Plan-Review-2013-Volume-1.pdf.

Pacific civil society organisations, 2015, 'Open Letter to Forum Trade Ministers: Pacific civil society urgent open letter. Available at: www.pina.com. $\mathrm{fj} / \mathrm{p}=$ pacnews $\& \mathrm{~m}=$ read $\& \mathrm{o}=19175072215548149672 \mathrm{bbc} 2 \mathrm{a} 93 \mathrm{~d} 34$.

PACNEWS, 2015, 'Donors Influence Development Decisions: Forum SG', Papua New Guinea Today. Available at: news.pngfacts.com/2015/04/donorsinfluence-development-decisions.html. 
Samoa Observer, 2013, 'Trade Campaigner Kicked Out', Samoa Observer, 18 July. Available at: www.samoaobserver.ws/other/science-a-technology/6051-tradecampaigner-kicked-out.

South Pacific Forum Secretariat, 2000, 'Sharing Capacity: The Pacific experience with regional cooperation and integration', Suva, Fiji. Available at: akgul. bilkent.edu.tr/telekom/sharing-Experience.pdf.

Wesley-Smith, T. 2007, China in Oceania: New forces in Pacific politics, Pacific Islands Policy 2, East West Centre, Hawai'i i. Available at: www.eastwestcenter. org/fileadmin/stored/pdfs/pip002_1.pdf. 
This text is taken from The New Pacific Diplomacy, edited by Greg Fry and Sandra Tarte, published 2015 by ANU Press, The Australian National University, Canberra, Australia. 